Original Research Paper

\title{
Cash Flow Management at the Insurance Company Aimed at Provision of Financial Stability
}

\author{
${ }^{1}$ Elena Knyazeva, ${ }^{1}$ Larisa Yuzvovich, ${ }^{1}$ Elena Smorodina, \\ ${ }^{1}$ Valeria Fomenko and ${ }^{2}$ Vadim Katochikov \\ ${ }^{l}$ Yeltsin Ural Federal University, Ekaterinburg, Russia \\ ${ }^{2}$ Rosgosstrakh-Ural LLC, Directorate of Sverdlovsk Area, Ekaterinburg, Russia
}

Article history

Received: 21-12-2015

Revised: 11-02-2016

Accepted: 22-06-2016

Corresponding Author:

Larisa Yuzvovich

Yeltsin Ural Federal

University, Ekaterinburg,

Russia

Email: yuzvovich@bk.ru

\begin{abstract}
The insurance market of the Russian Federation is currently demonstrating the trend of slower growth rate of insurance premiums and problems, rising in certain sectors. The loss ratio of insurance operations is increasing along with reducing profitability of internal funds and assets, operational costs are growing. All these factors affect the financial stability of insurance companies and reduce the profitability of insurance business. There is no doubt that maintaining financial stability of insurance companies in the Russian insurance market under current conditions is an extremely important issue since this sector maintains stability of economic subjects in the most difficult economic situation, ensures the continuity of social reproduction and acts as the main provider of long-term investments to the country's financial market. To keep their position on the market, the insurance companies should pay special attention to maintaining stable positive cash flow and reducing the cash outflow. The approach to cash flow management in the insurance company proposed in the article accounts for existing challenges and opportunities can maintain the financial equilibrium of the company and can improve the efficiency of performance as well as reduce the need for debt capital and the insolvency risk of the insurer. The purpose of work is to identify the problems of financial stability and cash flow management in the insurance company and to develop practical recommendations aimed at addressing these problems based on generalization of the theoretical aspects and analysis of financial indicators. The scientific novelty of the research is in developing theoretical and methodological provisions and elaborating practical recommendations in the field of the insurance company's cash management in order to ensure financial stability.
\end{abstract}

Keywords: Cash Flow, Insurance Companies, Financial Stability

\section{Introduction}

\section{Statement of the Problem}

The activities in any organization imply emergence of cash flows, the efficiency and effectiveness of which will depend on the methods applied to manage them. The studies of many authors are devoted to the concept of cash flow (Brealey and Myers, 1997; Van Horne and Wachowicz, 2002; Helfert, 2003; Brigham and Ehrhardt, 2009; Bocharov, 2002, 2008; Blank, 2004; Kovalev, 2008; Kraft and Schwartz, 2015). The standard approaches to cash flow management are considered in the scientific literature, however, insurance companies, as business entities, have certain features that should be considered when analyzing and managing their cash flow (Kulikov, 2006; Nikulina and Berezina, 2007; Rinchino, 2009; Vavilova, 2011; Nikulina and Ushakov, 2015; Thimann, 2015). Insurance companies render a special kind of services-insurance coverage. To meet their obligations under insurance contracts, the insurers form a special fund-an insurance reserve which is not their own, but borrowed funds.

Volume and structure of financial resources of the insurance company should comply with the size and 
structure of the accepted insurance risks. The effectiveness of cash flow management determines the financial stability of the insurance company since imbalanced cash flows may lead to the situation when funds are insufficient for meeting the obligations and this leads to a risk of insolvency.

\section{Importance of the Problem}

The essence of the organization's financial stability is revealed in the works of authors, including Holt (1995; Hedderwick, 1996; Drury, 2002; Grachev, 2003; Demchuk, 2008; Isaeva, 2008; Ogorodnikov and Perunov, 2011). Adaptation of this concept to the insurance activities is carried out in the works by Lukonin, 2003; Fedorova (2009; Chernova, 2010; Khominich, 2011; Skamay, 2013). The multitude and relevance of the research on the financial stability of insurance business require enhanced studying of cash flow management in the insurance company. This area of research becomes ever more relevant in the context of current economic trends and changes in various sectors of the insurance business, increasing risks of insurance operations, capital consolidation and rising operational costs. The theoretical relevance of the research lies in the development of the theoretical and methodological basis of cash flow management in the insurance company aimed at ensuring financial stability. The practical relevance of the study is associated with the ability to apply the developed recommendations for the improved performance of the object of study-OJSC Alfa Strakhovanie as well as other insurance organizations.

\section{Practical Application}

Major findings and recommendations of the research were discussed and approved at international and Russian research and practical conferences. The findings of the research are used in the instruction at the Department of Insurance at the Yeltsin Ural Federal University as well as in the practices of Alfa Strakhovanie Company.

\section{Stating Hypothesis and Research Design}

Among the impacts on the cash flows of the insurance organization, aimed at improving its financial stability, the literature examines the increase in own funds, the increase in incoming cash flow amount, optimization of insurance payments, saving the costs of doing business, reducing accounts receivable and payable (Shikhov, 2012; Shevchenko and Rusak, 2012). From the authors' perspective, the growth of operational costs and accounts receivable, insufficient cash flow from investment activities are the main challenges to ensuring financial stability of OJSC Alfa Strakhovanie.

Increasing operational costs are the main factor of lower profits of the company. This primarily occurs due to the increase in acquisition costs. This is a typical problem for the whole Russia's insurance market. The growth of acquisition comes as a result of higher agency fees and increasing banking sales channel. Insurance companies should strive for optimization of personnel expenses and commissions since growing operational costs lead to lower current solvency of the insurance company.

Lower receivables turnover results from the insurer's prolonging the credit period for the counterparties. Receivables should be improved in terms of management-the period of commercial loan allocation to counterparties should be reduced, the same refers to accounts receivable collection period. The growth of receivables necessitates calling for additional sources of funding and increasing accounts payable.

The negative cash flow from investment activities, greater than the positive flow, leads to the situation of insufficient cash flow. Measures aimed at increasing the positive cash flow from the investment activities will affect the liquidity ratio of the cash flow. Among other indicators that reflect the need for reforms are lower profitability of financial and operating performance and a smaller share of their own funds in the structure of financial resources which occurs die to the changes of such financial resources as retained earnings and credit resources.

To solve these problems, from the authors' point-ofview, it is viable to develop and implement a more transparent and effective approach to the cash flow management in OJSC Alfa Strakhovanie. This approach should embrace certain operations and reflect what changes in the financial stability of the insurance company any of these operations is directed at.

\section{Method}

\section{Method of Statistical Monitoring}

In this study the authors used analytical and logicalstructural approaches, statistical and graphical methods for processing and presenting the data, as well as comparative economic analysis.

\section{Method of Analysis and Measurement}

In insurance company Alfa Strakhovanie financial resources include authorized, additional and reserve capital, retained earnings, insurance reserves, loans and accounts payable (Table 1).

In 2015 financial resources of Alfa Strakhovanie amounted for $18 \%$ of equity and $82 \%$ of borrowed capital (in 201416 and 84\%, in 201318 and 82\%, in 201223 and $77 \%$, respectively). The statistics demonstrate fluctuations in the share of the equity funds in the structure of financial resources, which is a negative trend. Insurance reserves constitute a considerable part in the structure of borrowed capital that account for $87.4 \%$ in 2015 and so do the borrowed funds and accounts payable. 
The scientific literature determines relationship of the organization's cash flow management and its financial stability indicators (Nikulina and Berezina, 2007; Kharseeva, 2011; Shevchenko and Rusak, 2012). Therefore the analysis of cash flows is one of the key elements when estimating the financial stability of the insurance company. Affluence of an insurance company largely depends on the cash flow that enables coverage of its obligations under insurance, coinsurance and reinsurance contracts (Table 2). We should also mention negative net cash flow from investment activities, which confirms the authors' hypothesis that this field of insurance company's activities should be regulated.

\section{Taxonomic Method}

The financial stability of the insurance company can be estimated by means of indicators such as cash flow liquidity ratio, current liquidity ratio, return on equity, return on financial and operating performance, equity ratio and the insurance reserves coverage ratio (Kulikov, 2006; Orlanyuk-Malitskaya, 2008; Rinchino, 2009; Kozlova and Rodionova, 2014) (Table 3).
The provision of cash flow liquidity is possible with the coefficient of not less than 1 . The value of the cash flow liquidity ratio shows a decrease in the rest of the money by the end of the period, which does not increase the overall solvency of the insurer. The insurance company's current liquidity ratio reflects the ability to turn assets into cash. The company is considered to be liquid if its cash and assets are sufficient for the timely repayment of obligations. The data in Table 3 show that the current liquidity ratio of Alfa Strakhovanie in 20132015 fell below 1, which indicates the increasing financial risk of the insurance company. The normal value of the current liquidity lies in the range of 1.5-2.5.

Return on equity reflects the efficiency of equity use, increasing cost effectiveness is linked with growing investment attractiveness of the company. The given data show that in 2013 there was a decrease in return on equity, which was caused by shrinking profits of the insurance company. The reduction in profit in 2013 was the result of the increase in losses and expenses for insurance activities. In 2014 return on equity began increasing, which was simulated by profit growth.

Table 1. Dynamics of financial resources composition and structure at Alfa Strakhovanie in 2012-2014.

\begin{tabular}{|c|c|c|c|c|c|c|c|c|}
\hline \multirow[b]{2}{*}{ Source of formation } & \multicolumn{2}{|l|}{2012} & \multicolumn{2}{|l|}{2013} & \multicolumn{2}{|l|}{2014} & \multicolumn{2}{|l|}{2015} \\
\hline & RUB '000 & Share $(\%)$ & RUB '000 & Share $(\%)$ & RUB ’000 & Share $(\%)$ & RUB '000 & Share $(\%)$ \\
\hline Equity, including: & $8,729,355$ & 100.0 & $8,434,922$ & 100.0 & $8,716,937$ & 100.0 & $11,247,653$ & 100.0 \\
\hline Authorized capital & $5,000,000$ & 57.3 & $5,000,000$ & 59.3 & $5,000,000$ & 57.4 & $5,000,000$ & 44.5 \\
\hline Additional capital & 9,312 & 0.1 & 9,312 & 0.1 & 9,312 & 0.1 & 9,312 & 0.1 \\
\hline Reserve capital & 121,949 & 1.4 & 186,419 & 2.2 & 186,697 & 2.1 & 215,798 & 1.9 \\
\hline Retained earnings & $3,598,094$ & 41.2 & $3,239,191$ & 38.4 & $3,520,928$ & 40.4 & $6,022,543$ & 53.5 \\
\hline Borrowed capital, including: & $29,586,822$ & 100.0 & $38,715,463$ & 100.0 & $44,274,451$ & 100.0 & $51,506,248$ & 100.0 \\
\hline Insurance reserves & $24,859,735$ & 84.0 & $33,117,693$ & 85.5 & $38,930,261$ & 87.9 & $44,998,064$ & 87.4 \\
\hline Borrowed funds & $1,300,000$ & 4.4 & $1,850,229$ & 4.8 & 91,489 & 0.2 & 355,284 & 0.7 \\
\hline Accounts payable & $3,427,087$ & 11.6 & $3,747,541$ & 9.7 & $5,252,701$ & 11.7 & $6,152,900$ & 11.9 \\
\hline
\end{tabular}

Table 2. Dynamics of cash flow at Alfa Strakhovanie in 2012-2014, thousand rubles.

\begin{tabular}{|c|c|c|c|c|}
\hline Cash flow & 2012 & 2013 & 2014 & 2015 \\
\hline \multicolumn{5}{|c|}{ Cumulative cash flow } \\
\hline Positive & $82,234,396$ & $97,070,710$ & $130,400,325$ & $131,139,026$ \\
\hline Negative & $87,160,482$ & $97,628,101$ & $129,181,338$ & $129,626,012$ \\
\hline Net cash flow & $-4,926,086$ & $-557,391$ & $1,218,987$ & $1,513,014$ \\
\hline \multicolumn{5}{|c|}{ Including cash flow from investments } \\
\hline Positive & 44203465 & 49241656 & $59,366,489$ & $55,396,489$ \\
\hline Negative & 53846994 & 53522815 & $58,534,005$ & $59,513,494$ \\
\hline Net cash flow & -9643529 & -4281159 & 832,484 & $(4,117,10)$ \\
\hline
\end{tabular}

Table 3. Dynamics of Alfa Strakhovanie financial stability in 2012-2014

\begin{tabular}{lccrr}
\hline Indicator & 2012 & 2013 & 2014 & 2015 \\
\hline Cash flow liquidity ratio & 0.94 & 0.99 & 1.01 & 1.01 \\
Current liquidity ratio & 1.01 & 0.91 & 0.92 & 0.99 \\
Return on equity, \% & 19.00 & 1.00 & 6.00 & 4.00 \\
Return on financial and operating performance, \% & 1.30 & 0.10 & 0.60 & 0.50 \\
Insurance reserves coverage ratio, \% & 44.00 & 35.00 & 34.00 & 32.00 \\
Equity ratio, \% & 23.00 & 18.00 & 18.00 & 18.00 \\
\hline
\end{tabular}


The profitability of financial and economic performance of the insurer is described through the amount of profit per ruble spent on current and investment operations. According to the presented data, there is a decrease in the profitability of financial and economic performance of Alfa Strakhovanie, which also resulted from the decline in the amount of profit. Profit growth in 2015 led to an increase in the profitability of financial and economic performance up to $0.5 \%$.

The coverage of insurance reserves with Alfa Strakhovanie's equity is decreasing; the growth rate of the company's equity is not as fast as the growth of its insurance reserves. In 2015, the coverage of insurance reserves with Alfa Strakhovanie's equity was 32\%, which calls for special attention since this rate should not go below $30 \%$.

The overall level of the insurance company's financial stability can be assessed by means of an indicator such as the equity ratio: The higher the value of this indicator is the higher is the level of financial stability. The data in Table 3 represent a tendency of decreasing equity availability and, consequently, decreasing financial stability of Alfa Strakhovanie from $23 \%$ in 2012 to $18 \%$ in 2015 , which also calls for special attention. To change this situation, the insurance company should either increase its equity or reduce the obligations.

\section{Method of Observational Generalization and Logical Inference}

As a part of the study, the authors developed an innovative approach to the cash flow management for Alfa Strakhovanie which takes into account the identified challenges and which is aimed at providing financial stability of the insurance company (Fig. 1).

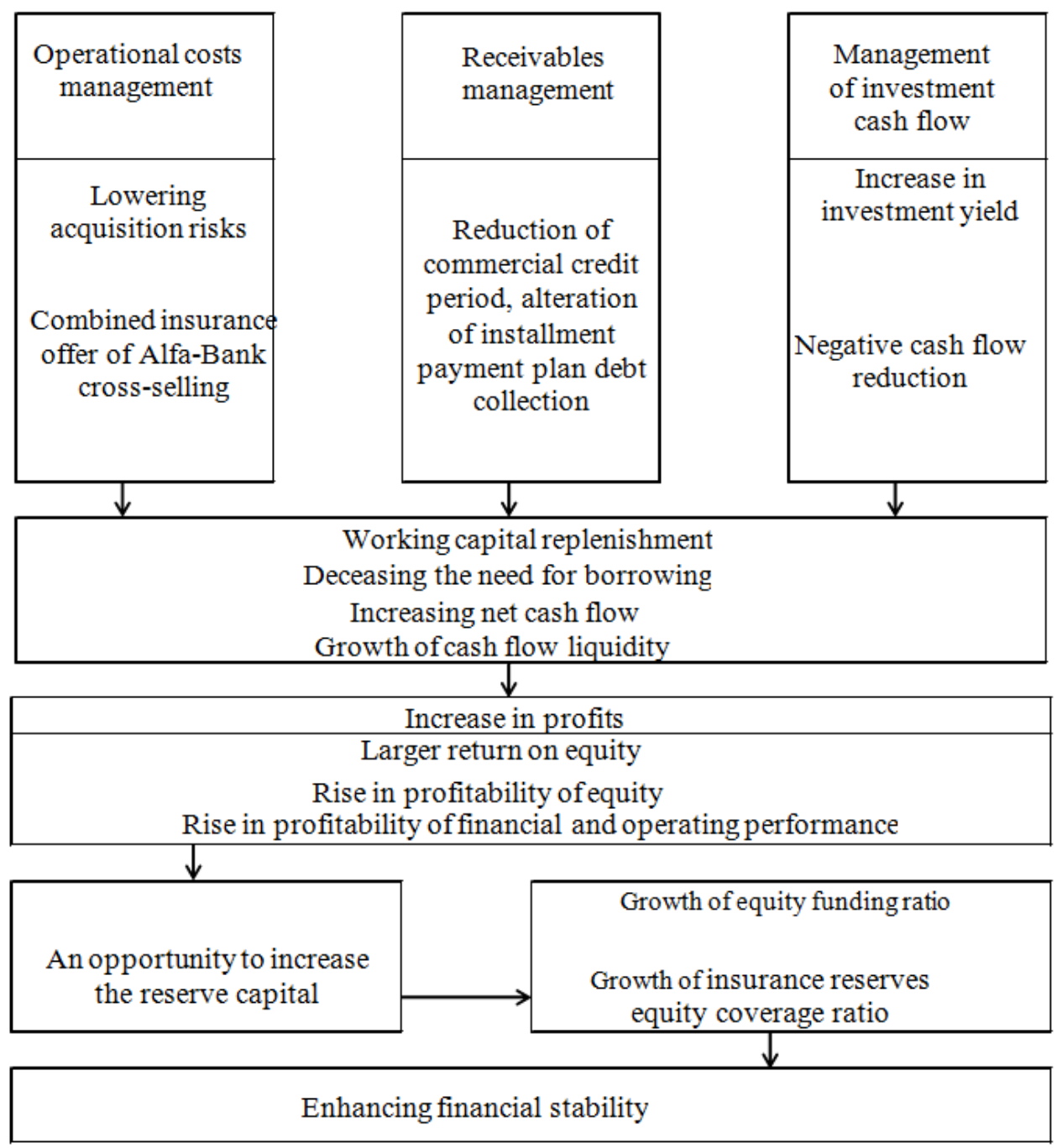

Fig. 1. The author's approach to the cash flows management aimed at enhancing financial stability of Alfa Strakhovanie 


\section{Results}

According to the proposed approach, the main lines of cash flow management at Alfa Strakhovanie should be managing operational costs, receivables and management of the cash flow from investment operations. Operational costs management involves lowering acquisition costs, offer of combined insurance products (for example, property and general liability insurance) and development of cross-selling and the use of Alfa-Bank resources.

Management of accounts receivable should focus on renegotiation of the installment payment plan, reduction of commercial credit period provided to counterparties and the implementation of measures for debt collection. It is necessary to recognize and analyze the current receivables, estimating past due rate, overdue period and causes of the delay in payments. Management of cash flow from investment operations involves revision of investment pattern in order to choose more profitable ones, as well as reduction in negative cash flow.

These measures will allow replenishing of the current capital, reducing the need for additional credit resources, increasing the total net cash flow and improving its liquidity, which will ultimately form the basis for the insurer's earnings growth. The profit growth will have a positive impact on financial solvency, return on equity and increase the profitability of the company's financial and operating performance.

In addition, growing profitability enables additional allocations to reserve capital, i.e. the increase in the insurance company's equity without additional shares. Increasing the company's equity will increase the equity ratio and insurance reserves coverage ratio. Carrying out of these recommendations will enhance the solvency and financial stability of the insurance company in the current economic conditions.

We should consider the issue of information technology implementation which may help to reduce costs. Automation of business processes in insurance business is a challenging and highly relevant issue. It should be mentioned that in the insurance business the application of information technology turns out to be quite complicated due to certain special features related to the automation of business processes in this field.
Analysis of historical data, economic and social aspects and other factors are the crucial factors of the development of new insurance products and the strategic directions for activities.

Qualitative and comprehensive analysis is possible only with application of modern technology at the stages of accumulation of information and its analysis. What's more, the specific feature of the insurance business is that business processes are interconnected, which requires the automation of all processes as a whole. The benefits of information technology include improved interaction between insurance companies, more efficient employee performance, an opportunity to carry out a situation analysis during strategic planning, adequate cash management, etc.

Implementation of the authors' approach to the cash flow management in the insurance company will influence its main indicators that reflect its financial stability (Table 4). Its further maintenance will bring the company's financial and economic profitability ratio to the level of 2012 of $1.3 \%$.

Despite the fact that insurance premiums are sufficient for covering claims and expenses incurred and the annual increase in Alfa Strakhovanie premiums, there are certain negative trends affecting the solvency and financial stability of the insurance company. Here, we should consider the indicators that describe equity. The increase in equity, along with maintaining the current level of profit will lead to a greater reduction in its return. That is why one should keep in mind that changes in the amount of own funds shall be carried out parallel to the measures, aimed at increasing the insurer's profits.

The proposed approach purports special attention to operational costs, accounts receivable, cash flow from investment operations with constant monitoring of the compliance with equity standards to ensure the solvency and financial stability. Implementation of the authors' approach can improve the financial stability of the insurance company. In this respect we should be mention that the proposed approach was tested at Alfa Strakhovanie and accounts for the special features of the company, so when applied at other organizations, this approach can show a result, different from one presented in this study.

Table 4. Projected changes in indicators of the financial stability of Alfa Strakhovanie due to the implementation of the proposed approach to the cash flow management

\begin{tabular}{lccc}
\hline Indicator & 2015 & Forecast for 2017 & Threshold value \\
\hline Cash flow liquidity ratio & 1.01 & 1.03 & Not lower than 1.0 \\
Current liquidity ratio & 0.99 & 1.02 & Not lower than 1.0 \\
Return on equity, \% & 4.00 & 6.00 & Not lower than $3 \%$ \\
Return on financial and operating performance, \% & 0.50 & 1.10 & Not lower than $1.3 \%$ \\
Insurance reserves coverage ratio, \% & 32.00 & 34.00 & Not lower than $30 \%$ \\
Equity ratio, \% & 18.00 & 23.00 & Not lower than $20 \%$ \\
\hline
\end{tabular}




\section{Discussion}

Approaches to cash flow management can be classified as conservative, moderate and aggressive. Characteristics of approaches are presented in Fig. 2.

A conservative approach implies the minimum application of borrowed money, creation of provisions and large account balance. This approach can provide a high level of financial stability, but at the expense of profitability. Moderate approach purports investment activities, the formation of a smaller amount of reserves and account balance than with a conservative approach. This approach can ensure the financial stability of the company, but allows for the risks associated with investment activities. The aggressive approach is the most risky and requires minimum reserves and account balance as well as investments in highly liquid assets.

The authors' approach to the cash flows management differs from existing approaches as, firstly, it combines the principles of the standard approaches, considered above (for example, tightening receivables policy, the development of investment activities) and, secondly, this approach is enriched with additional aspects. In addition to such areas as working with the reserves, credit policy, account balance and investment policy, the authors consider the policy of operational costs and equity management (including the reserve capital) that are not taken into consideration in the traditional approaches. The authors also recommend the adjustment of activities, depending on the changes in the indicators that reflect the financial stability of the insurance company. This should be carried out on the basis of the monitoring results.

Figure 3 shows the comparison of standard approaches to cash flow management and the authors' approach, according to the criteria such as universality and specific features of the insurance company.

Figure 4 represents strong and weak sides of popular approaches and the authors' approach to the cash flow management by the insurance companies according on the following criteria: The amount of reserves and account balance, credit policy, investment policy, the policy of cost management and the amount of own funds, the sequence of actions.

\begin{tabular}{|c|c|c|}
\hline \multicolumn{3}{|c|}{ APPROACHES TO THE COMPANY'S CASH FLOW MANAGEMENT } \\
\hline Conservative & Moderate & Aggressive \\
\hline $\begin{array}{l}\text { Formation of a larger volume of } \\
\text { reserve stocks }\end{array}$ & $\begin{array}{l}\text { Creation of provisions } \\
\text { in case of typical failures }\end{array}$ & Minimum reserves \\
\hline $\begin{array}{l}\text { Tough lending policy, } \\
\text { minimum grace period }\end{array}$ & $\begin{array}{c}\text { Standard terms of supply and } \\
\text { payment }\end{array}$ & $\begin{array}{l}\text { Long grace period, } \\
\text { flexible lending policy }\end{array}$ \\
\hline Large account balance & $\begin{array}{c}\text { Relatively small account } \\
\text { balance and risk-free financial } \\
\text { investment }\end{array}$ & $\begin{array}{l}\text { Minimum account balance, } \\
\text { investing available funds } \\
\text { in highly liquid assets }\end{array}$ \\
\hline
\end{tabular}

Fig. 2. Standard approaches to cash flow management

\begin{tabular}{|c|c|c|}
\hline $\begin{array}{c}\text { Approaches to cash flow } \\
\text { management }\end{array}$ & Universality & Consideration of specific features \\
\hline Standard & $\begin{array}{c}\text { Universal, may be used at most organizations, } \\
\text { enables a choice of three different types of } \\
\text { policy }\end{array}$ & $\begin{array}{c}\text { Does not consider the specific features of an } \\
\text { insurance company }\end{array}$ \\
\hline Proposed by the authors & $\begin{array}{c}\text { Is not universal and is aimed at solving } \\
\text { current problems of the company, requires } \\
\text { additional analysis for use in other } \\
\text { organizations }\end{array}$ & $\begin{array}{c}\text { Takes into account the specific features of the } \\
\text { insurance company regarding the need for } \\
\text { insurance reserves, the uncertainty involved } \\
\text { in payment of insurance claims and } \\
\text { investment activities }\end{array}$ \\
\hline
\end{tabular}

Fig. 3. Comparison of standard approaches to cash flow management and the authors' approach 


\begin{tabular}{|c|c|c|c|}
\hline Conservative & Moderate & Aggressive & Proposed by the authors \\
\hline \multicolumn{4}{|c|}{ Volume of stock and account balance } \\
\hline $\begin{array}{l}\text { (+) allows to maintain financial } \\
\text { stability in the event of } \\
\text { unforeseen expenses } \\
\text { (-) lost profits from alternative } \\
\text { investments }\end{array}$ & $\begin{array}{l}(+) \text { balance of risks and } \\
\text { opportunities } \\
(-) \text { none }\end{array}$ & $\begin{array}{l}\text { (+) funds are allocated to } \\
\text { other more profitable areas } \\
\text { (-)the risk of losing financial } \\
\text { stability in the event of } \\
\text { unforeseen expenses }\end{array}$ & (-) does not define \\
\hline \multicolumn{4}{|c|}{ Credit policy } \\
\hline $\begin{array}{l}(+) \text { minimization of accounts } \\
\text { receivable } \\
(-) \text { loss of solvent counterparties }\end{array}$ & $\begin{array}{l}(+/-) \text { standard terms of } \\
\text { working with counterparties, } \\
\text { moderate volume of accounts } \\
\text { receivable }\end{array}$ & $\begin{array}{l}(+) \text { working with solvent } \\
\text { counterparties } \\
\text { (-) unfounded growth of } \\
\text { accounts receivable }\end{array}$ & $\begin{array}{l}(+) \text { considers existing } \\
\text { problems, aims to reduce } \\
\text { accounts receivable }\end{array}$ \\
\hline \multicolumn{4}{|c|}{ Investment policy } \\
\hline $\begin{array}{l}(+) \text { minimization of financial } \\
\text { risks } \\
\text { (-) lost profits from alternative } \\
\text { investments }\end{array}$ & $\begin{array}{l}(+) \text { moderate investment risk } \\
(-) \text { no profits from } \\
\text { investments in highly liquid } \\
\text { assets }\end{array}$ & $\begin{array}{l}\text { (+) profits from investments } \\
\text { in highly liquid assets } \\
\text { (-) lost profits due to } \\
\text { investment risk }\end{array}$ & $\begin{array}{l}(+) \text { enables maintaining a } \\
\text { balanced cash flow from the } \\
\text { investment operations, does } \\
\text { not restrict investment } \\
\text { activities }\end{array}$ \\
\hline \multicolumn{4}{|c|}{ Policy of cost management and the amount of own funds } \\
\hline (-) ignores & $(-)$ ignores & (-) ignores & $(+)$ accounts for \\
\hline \multicolumn{4}{|c|}{ Sequence of actions } \\
\hline (-) not applicable & (-) not applicable & (-) not applicable & $(+)$ provided \\
\hline
\end{tabular}

Fig. 4. Advantages and disadvantages of traditional approaches and the authors' approach to the cash flow management in the insurance company

The financial health of the insurance company is described through its financial stability. The concept "the insurer's financial stability" may be interpreted in a number of ways. Fedorova (2009) defines financial stability as a state of financial resources at which the insurer is able to timely and fully complies with its obligations (both current and future) at the expense of its own and borrowed funds. According to the definition proposed by Orlanyuk-Malitskaya and Yanova (2011), the insurer's financial stability is determined by its ability to perform at any time (in the present or in the future) their obligations, especially under the contracts. Aliev and Mahdieva (2014) define the financial stability of the insurance company as the ability to fulfill its obligations to all parties timely and fully at its own and borrowed funds.

Such authors as Arkhipov et al. (2008) believe that the financial stability of the insurance company is formed by two components-solvency and financial capacity which enable coping with possible changes in the external environment. According to Skamay (2013), an insurance company can be regarded as financially stable if its financial stability results from the sufficient share of equity in the composition of financing sources. Khominich (2011) states that the financial stability of the insurance company should be understood as the ability to maintain solvency level over a certain period of time regardless of possible negative internal and external impact on cash flows. Chernova (2010) considers financial stability of the insurance company as the ability to perform insurance liabilities, being exposed to unfavorable factors and changes in economic situation. In contrast to the previous definitions, the latter emphasizes the importance of the impact of internal and external factors on the solvency of the company.

Shikhov (2012) defines the financial stability of the insurer as the material and financial conditions of the insurance company, where the size and structure of their own finds and their equivalents, liquid assets (which reflect the efficiency of financial management, insurance activities management, its new areas, as well as the efficiency of insurance operations and cost-cutting) provide a certain level of solvency at any specific time. This definition is closest to the authors' understanding of the issue, as it considers the impact of financial management, including cash flow management, of the insurance company on its financial stability.

Factors which influence the financial stability of the insurance company are considered by many researchers working in the field of economists (Orlanyuk-Malitskaya and Yanova, 2011; Khominich, 2011; Arkhipov, 2012; Shikhov, 2012; Aliev and Mahdieva, 2014; Filipovic et al., 2014). The factors are classified in Fig. 5.

All factors can be divided into two groups-the factors of external and internal environment. External factors are rather difficult to influence, but it is possible to control the internal factors. The insurance company has to adapt to external factors, while it can use internal factors to effectively deal with negative influence and take full advantage of the beneficial effects of external factors. 


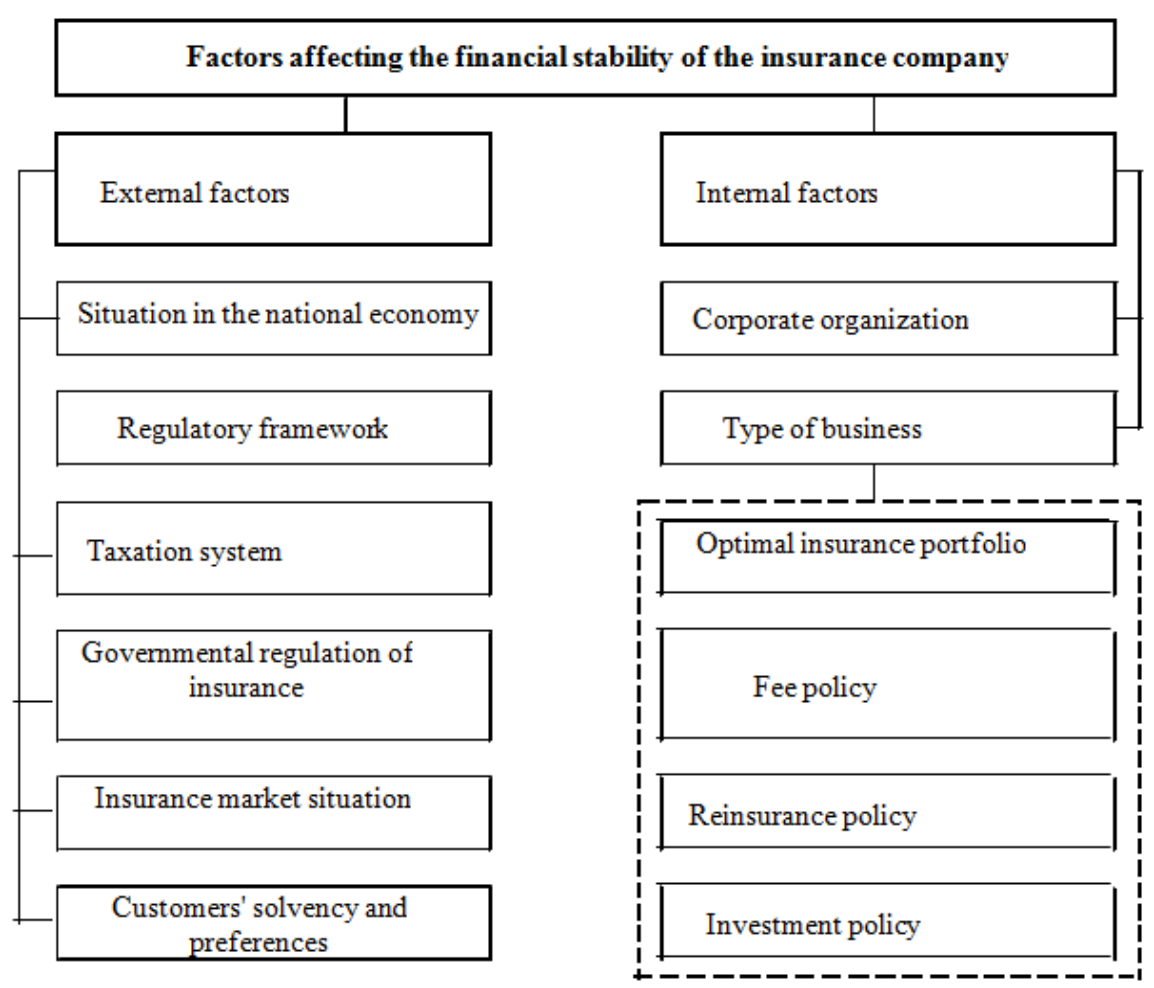

Fig. 5. Classification of factors, affecting the financial stability of the insurance company

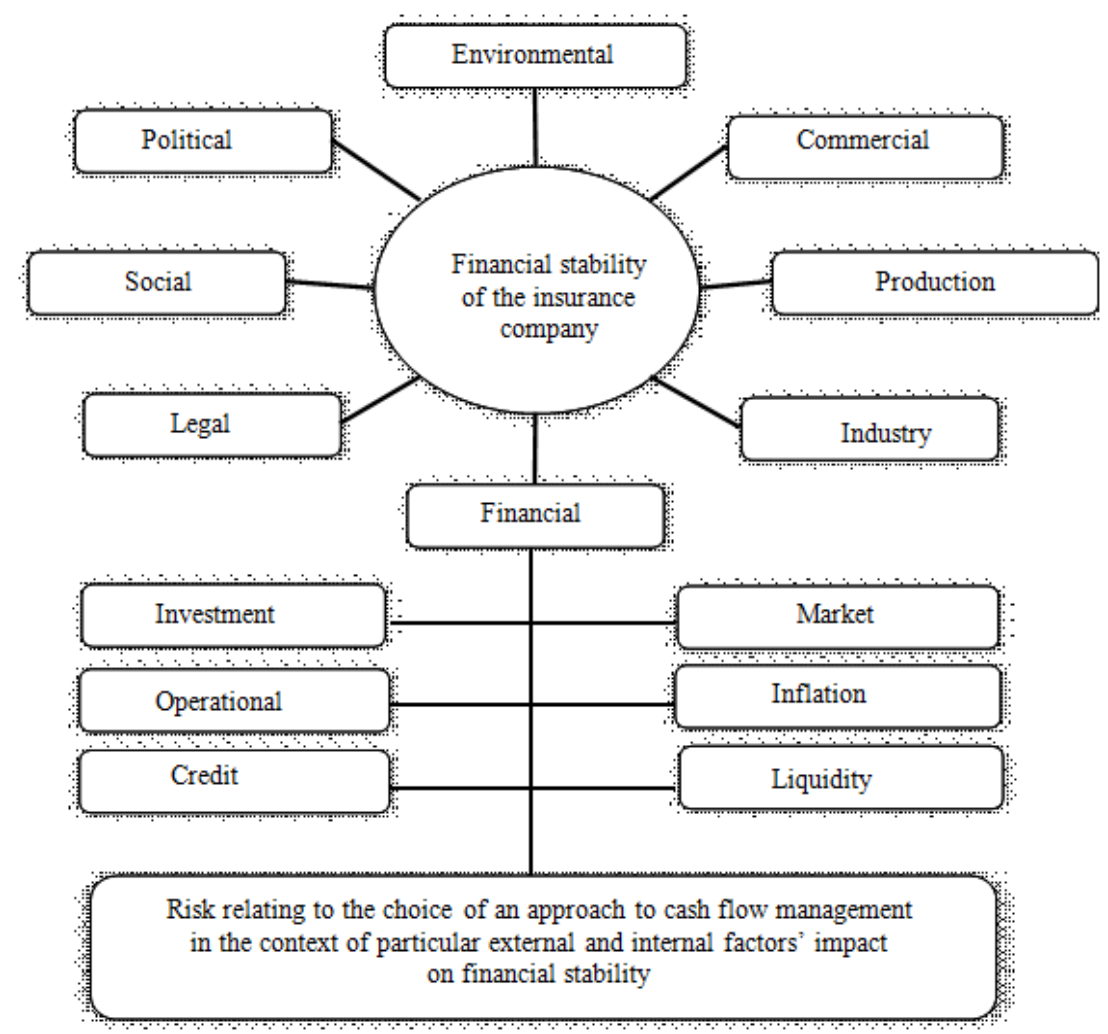

Fig. 6. Risks affecting the financial stability of the insurance company 
Classification of factors into internal and external ones is common in the academic papers, regardless of the particular field of the research object. External factors, so-called "framework conditions", do not vary significantly as different organizations (insurance, credit, service sector) operate in a single field, especially in the context of integration and globalization. The authors believe that at present moment the emphasis should be placed on the internal factors affecting the financial stability of the insurance company since they are actually the main reasons undermining the financial stability of the insurance company.

In contrast to traditional approaches, the authors' classification focuses on the factor relating to the type of business (optimal insurance portfolio, fee, reinsurance and investment policies). These factors were defined through identifying specific features of the insurance company's activities and with due account for their significant impact on financial stability. The authors see it as crucial to monitor the proposed factors of financial stability, identify the risks resulting from their impact and develop measures to deal with the risks identified. The authors' approach can be described as universal for companies working in the insurance market. For other companies (for example, credit, medical, educational, cultural institutions) the factor associated with type of business will have a different content, reflecting the specific nature of each particular area.

An insurance company is exposed to various risks. However, special attention should be paid to the group of financial risks (Fedorova, 2009; Chernova, 2010; Orlanyuk-Malitskaya and Yanova, 2011; Akhvlediani and Shakhov, 2012; Aliev and Mahdieva, 2014; Cummins and Weiss, 2014; French et al., 2015). The risks affecting the financial stability of the insurance company are presented in Fig. 6.

\section{Conclusion}

Having carried out the research and systematization of theoretical positions of the insurance business management, cash management and financial stability of the insurance company, the authors suggest adding new items to the list of risks. The financial risks that affect the financial stability of the insurance company were expanded by the authors with the risk relating to the choice of an approach to cash flow management in the context of particular external and internal factors' impact on financial stability. This risk deals with a probable reduction in the insurance company's financial stability due to selecting certain actions influencing the cash flows which conflict with the impact of external and internal factors.

The authors' approach to the cash flow management, developed after studying the specific features of the insurance company's activities and aimed at solving the problems typical of a particular organization, allows for more effective management than traditional approaches and enables achievement of both current and strategic goals.

\section{Acknowledgment}

The authors express sincere gratitude to Alesya Olegovna Pavlenko, assistant director at the Ural Regional Center of Alfa Strakhovanie for providing a representative sample of analytic data on the management of cash flow and financial stability of the insurance company.

\section{Author's Contributions}

Elena Knyazeva: He was responsible for determination of the research subject and research plan development, information collection and manuscript writing.

Larisa Yuzvovich and Elena Smorodina: Contributed to the information analysis and manuscript writing.

Valeria Fomenko and Vadim Katochikov: participated in the results analysis and article compiling.

\section{Ethics}

This article is original and contains unpublished material. The corresponding author confirms that all of the other authors have read and approved the manuscript and there are no ethical issues involved.

\section{References}

Akhvlediani, Y.T. and V.V. Shakhov, 2012. Insurance. UNITY-DANA, Moscow.

Aliev, B.K. and Y.M. Mahdieva, 2014. Insurance basics. UNITY-DANA, Moscow.

Arkhipov, A.P., 2012. Insurance. KNORUS, Moscow.

Arkhipov, A.P., V.B. Gomellya and D.S. Tulenty, 2008. Insurance: Modern course. INFRA-M, Moscow.

Blank, I.A. 2004. Financial management. Nika-Centr, Kiev.

Bocharov, V.V., 2002. Management of Money Turnover of Enterprises and Corporations. 1st Edn., Finansy i Statistika, Moscow.

Bocharov, V.V., 2008. Corporate Finance. 1st Edn., Finansy i Statistika, Moscow.

Brealey, R. and S. Myers, 1997. Principles of Corporate Finance. 1st Edn., Olymp-Business, Moscow.

Brigham, E.F. and M.C. Ehrhardt, 2009. Financial Management. 1st Edn., Piter, St.Petersburg.

Chernova, G.V., 2010. Insurance: Economics, Organization, Management. 1st Edn., Ekonomika, Moscow. 
Cummins, J.D. and M.A. Weiss, 2014. Systemic risk and the U.S. insurance sector. J. Risk Insurance, 81: 489-528. DOI: 10.1111 /jori.12039

Demchuk, I.N., 2008. Financial stability as a complex category of economic analysis. Siberian Finan. School, 5: 146-149.

Drury, C., 2002. Management and Cost Accounting. 1st Edn., YUNITI, Moscow.

Fedorova, T.A., 2009. Insurance. 1st Edn., Masters, Moscow.

Filipovic, D., R. Kremslehner and A. Muermann, 2014. Optimal investment and premium policies under risk shifting and solvency regulation. J. Risk Insurance, 82: 261-288. DOI: 10.1111/jori.12021

French, A., M. Vital and D. Minot, 2015. Insurance and financial stability. Bank Engl. Q, 3: 242-258.

Grachev, A.V., 2003. Foundations of the financial stability of the organization. Finan. Manage., 2: 32-47.

Hedderwick, K., 1996. Financial and Economic Analysis of Companies' Activity. 1st Edn., Finansy i Statistika, Moscow.

Helfert, E., 2003. Technics of Financial Analysis. 1st Edn., Piter, St. Petersburg.

Holt, R.N., 1995. Basics of financial management: Trans. from English. Delo., Moscow.

Isaeva, E.V., 2008. Problems of determining the essense of notion 'company's financial stability'. Problems Economy, 2: 78-81.

Kharseeva, A.V., 2011. Cash flow optimization as an element of managing stability of the company's financial state. Theory Pract. Public Dev., 7: 329-334.

Khominich, I.P., 2011. Insurance. 1st Edn., INFRA-M, Moscow.

Kovalev, V.V., 2008. Management of Cash Flows, Profitability and Efficiency. 1st Edn., Prospekt, Moscow.

Kozlova, O.N. and Y.S. Rodionova, 2014. Assessment of financial stability of the insurance company. Proceedings of the Conference "Prospects and Regularities of Modernization of the Modern Society: New Vision, pp: 213-217.

Kraft, H. and E. Schwartz, 2015. Cash flow multipliers and optimal investment decisions. Eur. Finan. Manage., 21: 399-429. DOI: 10.1111/eufm.12047
Kulikov, S.V., 2006. Financial Analysis of Insurance Organizations. 1st Edn., Feniks, Rostov-on-Don.

Lukonin, S.V., 2003. Financial stability of the insurance companies and ways of its enhancing. Insurance Bus., 5: 28-31.

Nikulina, N.N. and I.I. Ushakov, 2015. Paradigm of cash flow characteristics as an object of management in the insurance organization. Bull. Acad. Econ. Safety, 1: 86-90.

Nikulina, N.N. and S.V. Berezina, 2007. Analysis of cash flows in the insurance organization. Econ. Anal.: Theory Pract., 6: 36-41.

Ogorodnikov, P.O. and V.B. Perunov, 2011. Biotechnical approach to the analysis and forecasting of the company's financial stability. Econ. Reg., 2: 235-238.

Orlanyuk-Malitskaya, L.A. and S.Y. Yanova, 2011. Insurance. 1st Edn., Yurayt Publishing House, Moscow.

Orlanyuk-Malitskaya, L.A., 2008. Solvency of the Insurance Company. Ankil, 1st Edn., Moscow.

Rinchino, T.E. 2009. Financial stability of the insurance company and peculiarities of its analysis. Econ. Humanitarian Sci., 3: 209-214.

Shevchenko, I.V. and A.A. Rusak, 2012. Peculiarities of the company's cash flow optimization. Econ.: Theory Pract., 1: 26-31.

Shikhov, A.K., 2012. Insurance: Organization, Economics, Legal Aspects. 1st Edn., INFRA-M, Moscow.

Skamay, L.G., 2013. Insurance Business. 1st Edn., Yurayt Publishing House, Moscow.

Thimann, C., 2015. Systemic features of insurance and banking and the role of leverage, capital and loss absorption. Geneva Papers Risk Insurance, 40: 359-384. DOI: 10.1057/gpp.2015.13

Van Horne, J.C. and J.M. Wachowicz, 2002. Fundamentals of Financial Management. 1st Edn., Williams Publishing House, Moscow.

Vavilova, I.A., 2011. Organizational and methodical mechanism for managing cash flows of the insurance company. Actual Issues Econ. Sci., 18: 457-461. 